\title{
Effect of methanol extract of Tridax procumbens flower on hematological parameters and serum lipid profiles of Wistar albino rats
}

\author{
Felix Oghenemaro ENWA ${ }^{1 *}$, Johnson Daniel JEMIKALAJAH ${ }^{2}$, Michael OGHENEJOBO \\ and Victor Eseoghene OGHENEBRUME ${ }^{1}$ \\ ${ }^{1}$ Department of Pharmaceutical Microbiology, Faculty of Pharmacy, Delta State University, Abraka, Nigeria. \\ ${ }^{2}$ Department of Microbiology, Faculty of Science, Delta State University, Abraka, Nigeria.
}

Received $27^{\text {th }}$ November 2019; Accepted $10^{\text {th }}$ February 2020

\begin{abstract}
The aim of the study is to evaluate the effects of the methanolic extract of Tridax procumbens L. flower on the hematological and serum lipid profile of Albino Wistar rats. Ten male albino Wistar rats were obtained and divided into two groups (control and test). The flowers were extracted by cold maceration using methanol. The extract was then administered orally to the Test group at a dose of $100 \mathrm{mg} / \mathrm{kg} / \mathrm{d}$. Thereafter, blood samples were obtained from both groups and the hematological and serum lipid parameters were analyzed using auto-analyzers. The results of the hematological parameters obtained for Test group were; PCV-46.2\%, Hemoglobin-14.656 g/dl, Platelets-141.08 $\mathrm{mm}^{3}$, Eosinophil-4.0\%, Neutrophil-38\%, Mean corpuscular hemoglobin (MCH)-35.532pg, Mean corpuscular hemoglobin concentration (MCHC)-32.11gl and Mean corpuscular volume (MCV)-108.658 ft, which were higher compared to the Control; while that of the serum lipid profiles were determined to be; Cholesterol-142.58 mg/dl, Triglycerides-157.58 mg/dl, HDL-56.72 mg/dl, LDL-55.944 mg/dl and VLDL-31.516 mg/dl. The plants were seen to have slight weight reducing activity, no significant effect on total white blood cell count, increased eosinophils, neutrophils, packed cell volume, platelet count, mean corpuscular hemoglobin $(\mathrm{MCH})$, mean corpuscular hemoglobin concentration (MCHC), mean corpuscular volume (MCV), HDL, and reduced LDL, VLDL, triglycerides, cholesterol on the rats tested. Hence, from this study, this plant can serve as a good candidate to be used as a hematinic agent, as weight reducers, and a lipid lowering agent.
\end{abstract}

Keywords: Tridax procumbens, Wistar rat, $H D L, L D L M C V, M C H C$

\section{INTRODUCTION}

Plants, which form the bulk of foodstuffs in humans, is the primary source of many traditional medicine systems and folk medicines that have been practiced for several years during the course of human history. Until date, plants/herbs are still regarded to be of high importance worldwide as a rich source of therapeutic agents for treating and preventing diseases and ailments; presently, over 35,000 plant species are utilized for medicinal uses around the world [1]. The quest for novel drugs from plants/herbs continues to rapidly increase in the recent few decades, and this has resulted into the collection of a remarkably vast array of more

\footnotetext{
*Correspondence. E-mail: felixenwa@delsu.edu.ng Tel: +234-7038591019.

ISSN 0189-8442

(cc) BY-Nc 2020 Published by Faculty of Pharmaceutical Sciences, University of Jos, Nigeria. Under Creative Commons Attribution-NonCommercial 4.0 International License. https://creativecommons.org/licenses/by-nc/4.0/
} 
than 139,000 natural products [2]. These constituents are potential sources for developing drugs. Studies have shown the biological importance of Tridax procumbens. Traditionally, it is useful in treating dysentery, malaria, bronchial catarrh, stomach ache, diarrhea and high blood pressure. It also helps to check the presence or possibility of the occurrence of hemorrhage from cuts, bruises and wounds and to prevent hair from falling. It is said to have antiseptic, insecticidal, parasiticidal and hepatoprotective properties and also possesses depressant action on respiration [3-6]. Research has also shown that Tridax procumbens Linn. has weight reducing activity [7], and analgesic property [8], and the aqueous extract of the leaves were seen to have protective effects against cholesterol and salt loading (in Wistar albino rats) $[7,9]$.

\section{EXPERIMENTAL}

Materials. The flowers of Tridax procumbens Linn. were collected in Abraka, Ethiope East Local Government, Delta State, South-South Nigeria. Ethical approval obtained from Delta State Health management Board, Asaba.

Experimental animals. Ten (10) male albino Wistar rats, weighing averagely $200 \mathrm{~g}$, were used for the experiment. The animals were obtained from a private animal house in Abraka, Delta State and then acclimatized for 7 days and maintained on water and animal feed ad libitum.

Method. The Wistar rats were weighed and randomly selected into two (2) groups of 5 animals each and kept in rat cages. They were then administered the extracts for 7 days and sacrificed. Group A (Test Group) were administered methanol extract, while Group B (Control Group) were not administered any extract.

Administration of extract. The methanol extract of the Tridax flower was prepared from the powdered sample of the flowers. The flowers were extracted by cold maceration for 7 days. This was then filtered and concentrated in a water-bath. The extract was dissolved in an equivalent amount of solution and was administered at a dose of 100 $\mathrm{mg} / \mathrm{kg} / \mathrm{d}$ to the rats orally.

Animal sacrificing and sample collection. At the end of the period of treatment, the animals were sacrificed and blood samples collected and stored into EDTA and Heparin bottles for Hematological and Serum lipid profile analysis.

Hematological analysis. Hematological analysis was conducted using the Binocular light microscope (OLYMPUS). The parameters examined includes Red Blood Cell Count, White Blood Cell Count, Lymphocytes (L), Hemoglobin (HB), Platelet count (PLT), Eosinophil (E), Neutrophil (N), Packed cell volume (PCV), Mean Corpuscular Hemoglobin (Mch), Mean Corpuscular Hemoglobin Concentration (Mchc), Mean Corpuscular Volume (Mcv).

Serum lipid profile analysis. The serum was analyzed using the automated laboratory analyzer to determine the lipid parameters, which includes; Cholesterol (CHO), Triglycerides (TRI), High density lipoprotein (HDL), Low density lipoprotein (LDL), Very low density lipoprotein (VLDL).

\section{RESULTS AND DISCUSSION}

Table1. Shows the effect of the treatment on the mean and standard deviation weights of the animals before and after treatment. There was reduction in weight of the animals in the Control Group. On comparison with the weights obtained before and after treatment with the methanol extracts for those of the Test Group, there was also a reduction in their weights, different from their initial weights but not as high as those in the Control group. This therefore means that, the weight reducing effect of the methanol extract of the flowers, which this plant has, is not 
high, unlike those of the control that has a more reduction in weight. This can be further illustrated in fig 1.

From Table 2, Packed Cell Volume or Hematocrit (\%) for the Control group was $33.8 \%$, while that of the Test group was $46.2 \%$, indicating a boost in the total blood volume. The Hemoglobin $(\mathrm{Hb})$ for the Control was $10.57 \mathrm{~g} / \mathrm{dl}$ while that of the Test group was $14.65 \mathrm{~g} / \mathrm{dl}$, which is also an indication in the boosting effect of hemoglobin concentration. Although, the extract did not have much effect on the Red Blood Cell count, as the value for the Control was $5.06 \mathrm{~mm}^{3}$ and that for the Test animals was $4.81 \mathrm{~mm}^{3}$. The extract had little or no effect on the Total White Blood Cell count (Twbc) as the value for the Control was higher than that of the Test group. The Lymphocyte (L) value for the Control group and that of the Test group are almost the same, with differences that are almost insignificant. The Eosinophils and the Neutrophils, which are types of disease- fighting white blood cells and are released during inflammation, showed a little increase in their values, this therefore shows the ability of this plant to act as an anti-inflammatory agent and also boost the immunity of individuals when the extract is taken. There was an increase in the Mch, Mchc and Mcv values. The Mch, Mchc, Mcv values depend on an increase or decrease in the synthesis of hemoglobin and so these values increased due to the presence of increased amounts of hemoglobin being synthesized. Therefore, this helps to determine the presence or the occurrence of anemia in an individual and can be used to prevent hemorrhage.

In the serum lipid profile as illustrated in Table 3, the Cholesterol level (mg/dl) had a decrease in its value from $156.46 \mathrm{mg} / \mathrm{dl}$ for the Control group to $142.58 \mathrm{mg} / \mathrm{dl}$ for the Test group. In addition, Total Triglyceride level decreased from $176.12 \mathrm{mg} / \mathrm{dl}$ for the Control group to $157.58 \mathrm{mg} / \mathrm{dl}$ for the Test group.

Table 1: Weights of animals

\begin{tabular}{lll}
\hline & Test animals $(\mathrm{g})$ Mean \pm SD & Control animals $(\mathrm{g})$ Mean \pm SD \\
\hline Pretreatment & $226.16 \pm 40.025$ & $173.87 \pm 24.629$ \\
Posttreatment & $206.40 \pm 35.913$ & $148.054 \pm 26.778$ \\
\hline
\end{tabular}

Table 2: Hematological parameters of both the Control and Test groups

\begin{tabular}{|c|c|c|c|c|c|c|c|c|c|c|c|}
\hline & $\begin{array}{l}\mathrm{PCV} \\
(\%)\end{array}$ & $\begin{array}{l}\mathrm{Hb} \\
(\mathrm{g} / \mathrm{dl})\end{array}$ & $\begin{array}{l}\mathrm{RBC} \\
\left(\mathrm{mm}^{3}\right)\end{array}$ & $\begin{array}{l}\text { Platelet } \\
\left(\mathrm{mm}^{3}\right)\end{array}$ & $\begin{array}{l}\text { Twbc } \\
\left(\mathrm{mm}^{3}\right)\end{array}$ & $\mathrm{L}(\%)$ & $\begin{array}{l}\mathrm{E} \\
(\%)\end{array}$ & $\begin{array}{l}\mathrm{N} \\
(\%)\end{array}$ & $\begin{array}{l}\text { Mch } \\
(\mathrm{pg})\end{array}$ & $\begin{array}{l}\text { Mchc } \\
\text { (gl) }\end{array}$ & $\begin{array}{l}\text { Mcv } \\
(\mathrm{ft})\end{array}$ \\
\hline $\begin{array}{l}\text { Control } \\
\text { Animals }\end{array}$ & $\begin{array}{l}33.8 \pm \\
2.168\end{array}$ & $\begin{array}{l}10.578 \\
\pm .198\end{array}$ & $\begin{array}{l}5.064 \pm \\
0.4235\end{array}$ & $\begin{array}{l}118.266 \\
\pm 6.124\end{array}$ & $\begin{array}{l}9.826 \pm \\
0.800\end{array}$ & $\begin{array}{l}21.372 \\
\pm 0.737\end{array}$ & $\begin{array}{l}3.6 \pm \\
0.56\end{array}$ & $\begin{array}{l}37 \pm \\
4.472\end{array}$ & $\begin{array}{l}20.55 \pm \\
1.873\end{array}$ & $\begin{array}{l}30.98 \\
\pm 0.87\end{array}$ & $\begin{array}{l}69.8 \pm \\
9.5\end{array}$ \\
\hline $\begin{array}{c}\text { Test } \\
\text { Animals }\end{array}$ & $\begin{array}{l}46.2 \pm \\
2.864\end{array}$ & $\begin{array}{l}14.656 \\
\pm 1.018\end{array}$ & $\begin{array}{l}4.8 \pm \\
0.97\end{array}$ & $\begin{array}{l}141.1 \pm \\
6.1\end{array}$ & $\begin{array}{l}8.48 \pm \\
0.84\end{array}$ & $\begin{array}{l}21.88 \pm \\
0.566\end{array}$ & $\begin{array}{l}4 \pm \\
0.0\end{array}$ & $\begin{array}{l}38 \pm \\
8.367\end{array}$ & $\begin{array}{l}35.53 \pm \\
2.056\end{array}$ & $\begin{array}{l}32.1 \pm \\
0.85\end{array}$ & $\begin{array}{l}108.66 \\
\pm 7.502\end{array}$ \\
\hline
\end{tabular}

Hb-Hemoglobin, RBC-Red Blood Cell count, Twbc-Total white blood cell count, L-Lymphocyte, E-Eosinophil, NNeutrophil, Mch-Mean Corpuscular Hemoglobin, Mchc-Mean Corpuscular Hemoglobin Concentration, Mcv-Mean Corpuscular Volume

Table 3: Serum lipid values of the Wistar albino rats administered with the methanol extract of the flowers of Tridax procumbens

\begin{tabular}{lll}
\hline Serum lipid values & Control Animals & Test Animals \\
\hline CHO(mg/dl $)$ & $156.46 \pm 7.220$ & $142.58 \pm 10.719$ \\
TRI $(\mathrm{mg} / \mathrm{dl})$ & $176.12 \pm 12.625$ & $157.58 \pm 10.688$ \\
HDL $(\mathrm{mg} / \mathrm{dl})$ & $50.52 \pm 3.579$ & $56.72 \pm 4.489$ \\
LDL $(\mathrm{mg} / \mathrm{dl})$ & $70.056 \pm 8.573$ & $55.944 \pm 10.989$ \\
VLDL $(\mathrm{mg} / \mathrm{dl})$ & $36.562 \pm 2.637$ & $31.516 \pm 2.138$ \\
\hline
\end{tabular}

CHO (mg/dl)-Cholesterol, TRI (mg/dl)-Triglycerides, HDL (mg/dl)-High Density Lipoprotein, LDL (mg/dl)-Low Density Lipoprotein, VLDL-Very Low Density Lipoprotein 


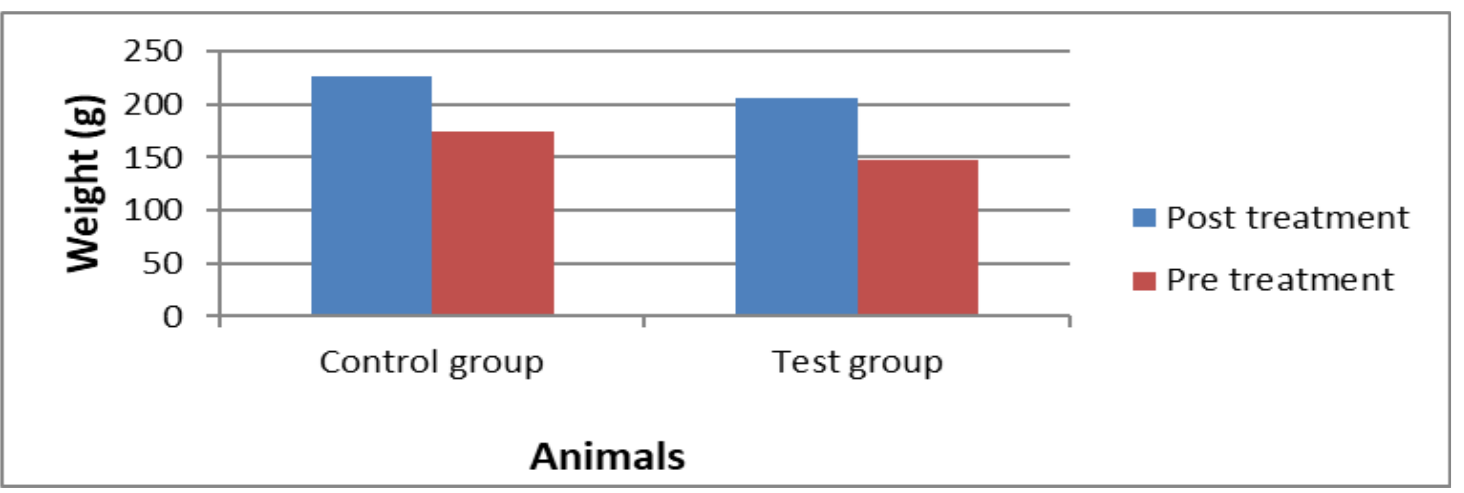

Fig 1 A bar chart showing the effect of the extract on test animals and those without, before and after treatment

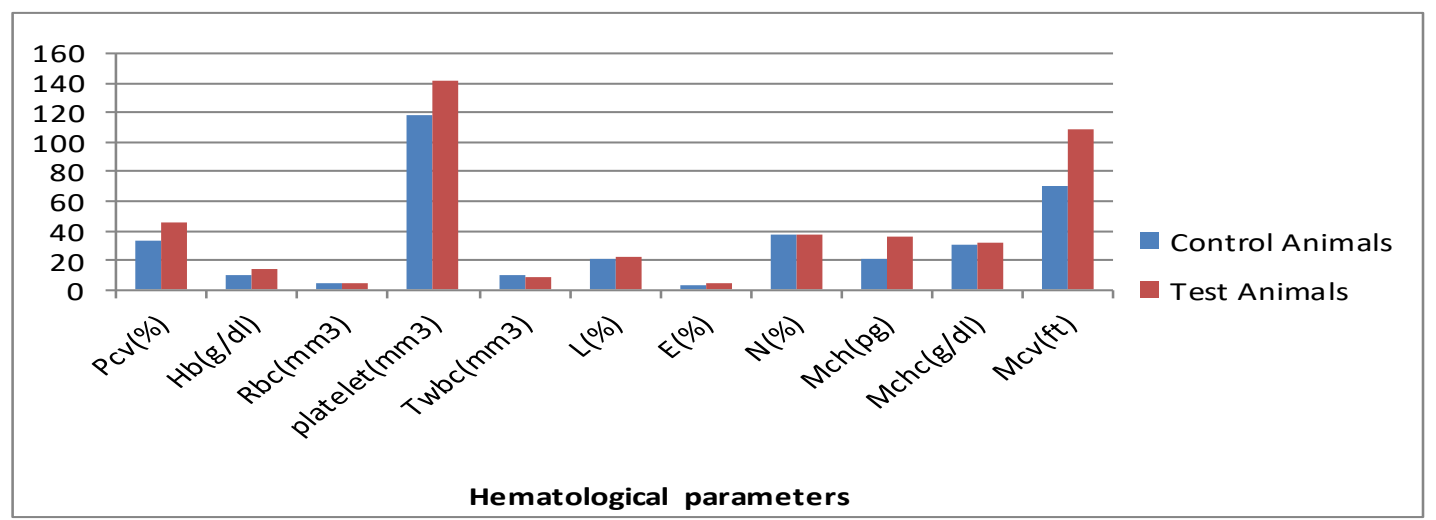

Fig 2 Hematological parameters of Wistar albino rats administered with methanol extract of the flowers Tridax procumbens

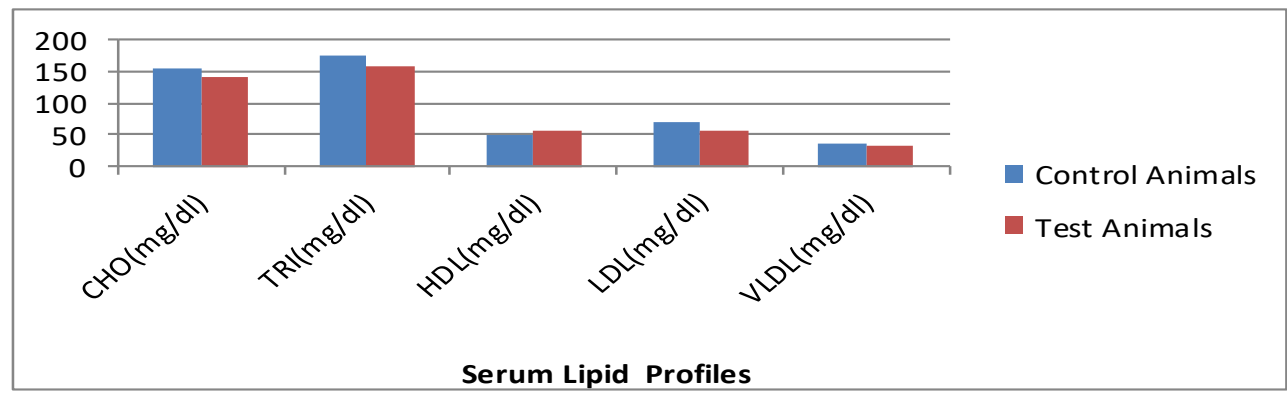

Fig3: A Bar Chart showing the effect of the methanol extract of the flowers of Tridax procumbens on the serum lipid profile of the Albino Wistar rats

Same thing goes for the LDL from 70.05 $\mathrm{mg} / \mathrm{dl}$ to $55.94 \mathrm{mg} / \mathrm{dl}$ for the Control and the Test groups respectively and that of the VLDL from $36.56 \mathrm{mg} / \mathrm{dl}$ to $31.516 \mathrm{mg} / \mathrm{dl}$ for the Control and the Test group respectively. The possibility of developing cardiovascular risks is due to the presence of increased levels of the lipoproteins and the total triglycerides and cholesterols. A decrease therefore, in the LDL, VLDL, triglycerides and cholesterols, helps to reduce the risk of cardiovascular diseases such as atherosclerosis. However, there is a lipoprotein that has beneficial effect i.e. it prevents the other lipoproteins from exerting their negative effect on the arterial wall and also prevents the influx of free fatty acids into the liver, this lipoprotein is the HDL, also called a "Good Cholesterol". An increased level of the HDL and a reduced level of the LDL will help to prevent the 
occurrence of cardiovascular diseases. The literature values for these serum lipid parameters include: below $200 \mathrm{mg} / \mathrm{dl}$, below $150 \mathrm{mg} / \mathrm{dl}$, above $50 \mathrm{mg} / \mathrm{dl}$, below $100 \mathrm{mg} / \mathrm{dl}$ and below $30 \mathrm{mg} / \mathrm{dl}$, which are for the cholesterol, triglycerides, LDL, HDL and VLDL respectively. The values were seen to fall within these desired values. Thus, indicating the anti-lipidemic effect of the Tridax flower.

Conclusion. In this study, the methanol extract increased the eosinophil and neutrophil levels, and so can be used to boost immunity. It can also have an antiinflammatory effect, which supports the study done by Nia et al. [10]. The Mch, Mchc, Mcv values were seen to be higher than the initial ones and so it is seen to have an anti-anemic effect. It also showed its ability to boost total blood volume by increasing PCV. The extract showed a marked decrease in the cholesterols, triglycerides and the lipoproteins LDL and VLDL, though the HDL value increased. This indicates its anti-lipidemic and can therefore prevent cardiovascular risks both due to an increment in weight and lipid levels, which supports the study done by Salahdeen et al. [3]; Ikewuchi et al. [9]. Therefore, the methanol extract of the flowers of Tridax procumbens Linn. can be suggested as a good drug candidate to immune compromised patients such as those that have undergone organ transplant, to help boost their immunity. It can also be suggested as a hematinic agent to patients having low blood volume. In addition, it can be administered to patients with cardiovascular disorders, in order to reduce its risks and also to obese individuals to reduce weight.

\section{REFERENCES}

1 Cameron S.I, Smith R.F, and Kierstead K.E, (2005) "Linking medicinal/nutraceutical products research with commercialization", Pharmaceutical Biology, 43(5): 425-433.

2 Boopathy Sithranga N. and Kathiresan K, (2010) Anticancer drugs from marine flora: an overview, Journal of Oncology, vol. 2010 p18.

3 Salahdeen HM, Yemitan OK, Alada ARA (2004). Effect of Aqueous Leaf Extract of Tridax procumbens on Blood pressure and Heart Rate on Rats. Afri. J. Biotech. Res. 7: 27-29.

4 Edeoga H.O, Okwu D. E, and Mbaebie B. O, (2005) Phytochemical Constituents of some Nigerian medicinal plants. Afr. J. Biotechnol., 4: 685-688.

5 Ravikumar, V., Shivashangari K.S and Devaki T, (2005). Hepatoprotective activity of Tridax procumbens against Dgalactosamine/lipopolysaccharide-induced hepatitis in rats. J. Ethanopharmacol., 101: 55-60.

6 Saxena, V.K. and Albert S, (2005). B-sitostreol-3-0$\beta$-D-xylopyranoside from the flowers of Tridax procumbens Linn. J. Chem. Sci., 117: 263-266.

7 Ikewuchi JC, Onyeike EN, Uwakwe AA, Ikewuchi CC. (2011) The weight reducing and hypocholesterolemic effect of aqueous extract of the leaves of Tridax procumbens Linn on sub- chronic salt-loaded rats. Intern J Biol Chem Sci, 5(2):680-7.

8 Prabhu VV, Nalini G, Chidambaranathan N, Kisan NS. (2011) Evaluation of anti-inflammatory and analgesic activity of Tridax procumbens Linn against formalin, acetic acid and CFA induced pain models. Int J Pharm Sci, 3:126-30.

9 Ikewuchi JC, Ikewuchi CC. (2010) Hypocholesterolaemic effect of aqueous extract of Acalypha wilkesiana "Godseffiana" Muell Arg on rats fed egg yolk supplemented diet: Implications for cardiovascular risk management. Res J Sci Tech, 2(4): 78-81.

10 Nia R, Paper D.H, Essien E.E, Oladimeji O.H, Iyadi K.C and Franz G. (2003) Investigation into invitro radical scavenging and in-vivo antiinflammatory potential of Tridax procumbens. Nigerian journal of physiological science, 18(1-2), 39-43. 